\title{
DEIXIS IN THE SPIDERWICK CHRONICLES MOVIE SCRIPT
}

\author{
Mira Ardeatika1, MelyyNurmala Setiawan² \\ 1 IKIP Siliwangi \\ 2 IKIP Siliwangi \\ 1mardeatika@gmail.com ,2 melyy.nurmala08@gmail.com
}

\begin{abstract}
Pragmatics is the study of the relationship between language and context that forms the basis of determining understanding of utterance. This study was entitled "An Analysis of deixis in The spider wick chronicles script". The problems of this study were what types of deixis are used in the spider wick chronicles script, and what is the dominant deixis used in The Spider wick Chronicles movie script. The objectives of this study were to find the types of deixis and to find the dominant of deixis in The spider wick Chronicles movie script. This study was purposed to find out the types and the dominant of deixis are used in The spider wick chronicles script. The script was get from internet. This study applied descriptive qualitative method. The following steps, it applied was the first, this study looked for the movie, the second, this study watched the movie, then, looked for the movie script of the movie "The spider wick chronicles", the fourth, this study identified the sentence of the movie script based on four types of deixis. From the analysis, it is found that there are four types : personal deixis, time deixis, place deixis, and discourse deixis.
\end{abstract}

Keywords: Pragmatic, deixis, the spider wick chronicles script

\section{INTRODUCTION}

Language is used as a media of communication. By language every people can transfer what we mean to other people.In the English language study there was five main components of micro linguistics,such as phonology,morphology,syntax,semantic and pragmatic.Pragmatic is the studies that explained the way in which context contributes to meaning. As Horn and Ward (2006, as cited in (Barron, Gu, \& Steen, 2017) underlined that Pragmatics is the study of the context-dependent aspects of meaning which are systematically abstracted away from in the construction of logical form. It means that pragmatics is a branch of linguistics that focuses on using of language and its meaning from the expressions and utterances through deixis, speech act, sense, reference and its meaning.

According to Charles W Keidler (1998 as cited in (Kreidler, 2013),deixis terms are used to refer to ourselves to others and object in our environment. They are used to locate actions in a time framerelative to the present. Deixis terms show social relationship the social location individuals in relation to others. They are also used to locate parts of text in relation to other parts.

Deixis can be found in a short story,novel and movie. This study analyzed a movie entitled the spiderwick chronicles. There were many dialogues and monologues in this movie that can be found and analyzed for finding out the deixis. 


\section{Types of Deixis}

In this researcher analyzed deixis in pragmatics. There are some of deixis but in this research, researcher focus on analyzed person deixis, place deixis, time deixis and discourse deixis in The Spider wick chronicles movie script.

\section{a. Person Deixis}

According to Levinson (1983 as cited in (Padilla Cruz, 1996) Personal deixis concerns the encoding of the role of participants in the speech event, in which the utterance in the question delivered.

b.Place Deixis

According to Yule (1996 as cited in (Terms, German, English, Deixis, \& Discourse, n.d.) place or spatial deixis is the relative location of people and things is being indicated.The place deixis mean is an experession used for show the location relative to the location of the participants in this speech event.

c.Time Deixis

Time deixis is another category of deixis expressions. It refers to an event of the utterance, which takes place anytime relative to the speaker said. The Example of time deixis, such as yesterday, tomorrow, now. The function of temporal deixis is to indicate time.

d. Discourse Deixis

According to Marmaridou (2006 as cited in (Benjamins et al., 2001) Discourse deixis is expressed with the term that are primarily used in make encode space or time deixis. The references is to know part of a discourse that can be only implemented by knowing where the current coding point or current reading/recording point is essentially deictic in character

\section{Movie}

Movie is a tool to convey various messages to the general public through storytelling. Movie is also interpreted as a medium of artistic expression for artists and film people to express their ideas and the story.The twins Simon Grace and Jared Grace (Freddie Highmore) and their sister Mallory (Sarah Bolger) had to move from New York after their parents' divorce. The three moved to Spider wick Estate in New England with Helen Grace (Mary-Louise Parker) their mother. Helen inherited the Spider wick Estate after the owner suddenly disappeared 80 years ago. Since their arrival at the Spider wick Estate, strange things began to happen. Some of their things began to disappear. At first they thought Jared was making a move because Jared actually objected to having to move from New York.

\section{METHOD}

Research design that used in this study was descriptive qualitative method. This Research was carried out by collecting the data, analyzing the data and presented the result of data analysis. In collecting data, the researchers used video and script from the internet. Then, the documentation was used for collect the data by gathering all kinds of documents related to deixis subject. The analysis started by knowing the kind of deixis then elaborated them using the theories used in this present study. Next, the data were classified based on their types by underlining the utterances of the characters analyzed.

\section{RESULTS AND DISCUSSION}

\section{Results}


Based on the findings, there are four types of deixis in the spider wick chronicles movie script. They are personal, place or spatial deixis , time, and discourse deixis. The data is summarized in the table below:

Table 1.type of deixis

\begin{tabular}{|c|c|c|c|}
\hline No. & Type of Deixis & The Script & Total \\
\hline 1. & $\begin{array}{l}\text { Personal Deixis: } \\
\text { First person }\end{array}$ & $\begin{array}{l}\text {-Iwas younger than you last time I was here, } \\
\text { Simon } \\
\text {-Well ,I know stuff you don' t. } \\
\text {-That's not gonna happen to me, or you }\end{array}$ & 3 \\
\hline & Second person & $\begin{array}{l}\text {-Stop! I'm not gonna let you keep acting like a } \\
\text { jerk! } \\
\text {-No, you won! Mom needs this to work, so cut } \\
\text { it out! } \\
\text {-Simon, don'tyou want to know where this thing } \\
\text { goes? }\end{array}$ & 2 \\
\hline & Third Person & $\begin{array}{l}\text {-I'm guessing she put it there. } \\
\text {-Why does he want that book so bad }\end{array}$ & 2 \\
\hline 2. & Place Deixis & $\begin{array}{l}\text {-Our crazy aunt stayed here her whole life and } \\
\text { never left, ever! } \\
\text {-Shut up. Something's in there, moving. }\end{array}$ & 2 \\
\hline 3. & Time Deixis & $\begin{array}{l}\text {-You're still coming tomorrow, right? } \\
\text {-You don't see us. But now you do but only if } \\
\text { we want you to. }\end{array}$ & 2 \\
\hline 4 & Discourse Deixis & $\begin{array}{l}\text {-This can't be happening. } \\
\text {-Let's not fall into old ruts, okay?I know this } \\
\text { house isn't perfect, but we can make it work, } \\
\text { All right? }\end{array}$ & 2 \\
\hline
\end{tabular}

\section{Discussion}

After the researcher analyzed the types of deixis in The spider wick chronicles on the script, we are get 4 types of deixis, such as person deixis, place or spatial deixis, time deixis and discourse deixis.

Based on analyzed the researcher found person deixis, It was divided by 3 parts there are first person deixis, consists of singular pronoun like (I,myself,me,mine), and plural pronoun like (we,us,ourselves), and the last is third person deixis like (she,him,her).

The second is a place deixis concerned where the dialogue was happened. It relates to Levinson (1983:62 as cited(Terms et al., n.d.)placeddeixis concerns with the encoding of spatial location relative to the location of the participants in the speech event, Place deixis or spatial deixis show location, place utterance in the movie.

In the spider wick chronicles movie script the dialogue place deixis there was: here ,there ,this place, a room.The third kinds of deixis is time deixis, is was concerned when to the time at which an utterance is spoken. In this movie script the researcher found 2 time deixis, there are : tomorrow and now.In addition, Levinson (1983:217 as cited in 
(Terms et al., n.d.) time deixis refers to the time which relative to the time of speaking or an utterance spoken.

According to Levinson (1983:85 cited in (Barron, Gu, \& Steen, 2017) "Discourse or text deixis concerns the use of expressions within some utterance to refer to some portion of the discourse that contains that the utterance. In this research the discourse deixis was found 2 there are: This and it. Refers to utterance something that the speaker say.

\section{CONCLUSION}

The kinds ofdeixis that used in The Spider Wick Chronicles" movie script were personal deixis, spatial deixis, temporal deixis and discourse deixis. In the spider wick chronicles movie script, there was 17 personal deixis. there is first person deixis ( 7 words), second person deixis (6 words), third person deixis (4 words). From the explanation of deixis above, we know personal deixis especially first person deixis is the most dominant in "the spider wick chronicles " movie script.

\section{ACKNOWLEDGMENTS}

For the pragmatic learners, students can use this research as the references in studying pragmatics especially in deixis expression and determining types of deixis, then the students can apply it,for communicate in their social life or in their daily activities. This research can be used by teachers as a pragmatic learning material in the classroom especially on deixis material, for increasing student interest and enthusiasm of student in learning, so the teacher can using several media like movie or video for learning , and the student will getting interested to learn it. This research still needs improvement in some parts, for further researchers who want to do research in the same field, this research can used it as a guide for give information and for getting better result of research.

\section{REFERENCES}

Barron, A., Gu, Y., \& Steen, G. (2017). The routledge handbook of pragmatics. The Routledge Handbook of Pragmatics, 1-580. https://doi.org/10.4324/9781315668925

Benjamins, J., Company, P., Núñez, G., María, J., Ferradá, M., \& Carmen, M. (2001). Marmaridou, s . (2000) Pragmatic Meaning and Cognition (Pragmatics and Beyond New Series ), Amsterdam /. 27250952(2000), 2000-2001.

Kreidler, C. W. (2013). Introducing English semantics, second edition. In Introducing English Semantics, Second Edition. https://doi.org/10.4324/9781315886428

Padilla Cruz, M. (1996). Pragmatics and Discourse Analysis I. Pragmatics. (June 2015), 1-4. https://doi.org/10.1002/9781405198431.wbeal1463

Terms, P., German, T., English, T., Deixis, H., \& Discourse, A. (n.d.). Pragmatics. 1-16. 